\title{
ELECTROMOTIVE FORCE OF CELLS AT LOW TEMPERATURES
}

\author{
By G. W. Vinal and F. W. Altrup
}

\section{ABSTRACT}

The practical importance of a knowledge of the electromotive behavior of dry cells and storage batteries at low temperatures has arisen from their use in the Arctic and at high altitudes. Measurements on dry cells and storage batteries cooled to $-72^{\circ} \mathrm{C}$ by carbon dioxide snow and to $-170^{\circ} \mathrm{C}$ by the use of liquid air were made. The Gibbs-Helmholtz equation was applied to the observations, and excellent ayreement between theory and observation was found. At the lowest temperatures high values of voltage were sometimes observed, and the polarity was often reversed. A possible explanation based on the Nernst equation is given.

The practical importance of a knowledge of the electromotive behavior of dry cells and storage batteries at low temperatures has arisen from their use in the Arctic and at high altitudes. In June, I92I, the Department of Terrestrial Magnetism of the Carnegie Institution, through Dr. S. J. Mauchly, requested the Bureau of Standards to furnish information in answer to the following questions: (I) What is the open circuit voltage of dry cells at approximately $0^{\circ} \mathrm{F}$ and below? (2) Are dry cells fit for use after they have been frozen and thawed out again? Since there was no reliable information available on this subject, some experimental work was undertaken, which included observations on storage batteries also. In the first experiments the temperature range was extended to $-72^{\circ} \mathrm{C}$, and as the open circuit voltage of the cells was not materially changed by cooling them to this temperature the work was extended to $-170^{\circ} \mathrm{C}$ because of the theoretical interest in the application of the Gibbs-Helmholtz and Nernst equations to these cells.

Two methods for cooling the cells were employed. For the range +25 to $-72^{\circ} \mathrm{C}$ the cells were submerged in a gasoline bath to which small amounts of carbon dioxide snow were added gradually until the lowest temperature attainable was reached, when an excess of the snow was packed around the cells. For the range +20 to $-170^{\circ} \mathrm{C}$ liquid air was used for cooling. The dry cells 
were placed in a double-walled glass jacket similar to a Dewar vessel, but having air at atmospheric pressure between the walls. This was submerged in liquid air contained in a larger Dewar flask. The storage cell, contained in a glass test tube, was similarly arranged with the addition of a ground cork packing to protect it from breakage. By this meats the cooling was gradual, about two hours being required for the cells to fall from room temperature to the lowest temperature available.

The temperatures were measured by a thermocouple of standardized constantan and copper wire. Since it was not practicable to insert the thermocouple in the dry cells of which the emf was measured, the thermocouple was placed at the center of a similar dry cell which was grouped symmetrically with the other cells. The temperature of the storage cell was measured by placing the thermocouple, protected by a thin-walled glass tube, in the electrolyte between the positive and negative plates of the cell. The electromotive forces of the thermocouples were read on a highresistance potentiometer.

The dry cells were $3 / 4$ inch diameter by $21 / 8$ inches high and were taken from flashlight batteries of a well-known make. A few experiments on silver chloride dry cells were made also. The storage cells were made by cutting strips of suitable size from the pasted plates of an automobile starting and lighting battery. These were placed in test tubes about $\mathrm{I}$ inch in diameter, with perforated hard-rubber separators and a few glass beads. The electrolyte was adjusted to a specific gravity of $\mathrm{r} .275$ to $\mathrm{x} .28 \mathrm{o}$ at the end of five days of continuous charging at 0.4 ampere.

TABLE 1.-Open Circuit Voltages of Cells

[For values below $-70^{\circ} \mathrm{C}$, see Flg. 2]

\begin{tabular}{|c|c|c|c|c|c|c|c|}
\hline Temperature $\left({ }^{\circ} \mathrm{C}\right)$ & $\begin{array}{l}\text { Ordi- } \\
\text { nary dry } \\
\operatorname{cell} a\end{array}$ & $\begin{array}{l}\text { Storage } \\
\text { cell } a\end{array}$ & $\begin{array}{c}\text { Silver } \\
\text { chloride } \\
\text { cell } b\end{array}$ & Temperature $\left({ }^{\circ} \mathrm{C}\right)$ & $\begin{array}{l}\text { Ordi- } \\
\text { nary dry } \\
\text { cell } a\end{array}$ & $\begin{array}{l}\text { Storage } \\
\text { cell } a\end{array}$ & $\begin{array}{l}\text { Silver } \\
\text { chloride } \\
\text { cell } b\end{array}$ \\
\hline & Volts & Volts & Volts & & Volts & Volts & Volts \\
\hline $20 \ldots$ & 1.540 & 2.116 & 1.06 & $-30 \ldots \ldots$ & 1.508 & 2.100 & 1.01 \\
\hline $10 \ldots$ & 1.537 & 2.113 & 1.05 & $-40 \ldots \ldots$ & 1.530 & 2.096 & 1.00 \\
\hline $0 \ldots .$. & 1.533 & 2.111 & 1.04 & $-50 \ldots \ldots \ldots \ldots \ldots$ & 1.540 & 2.092 & .99 \\
\hline$-10 \ldots$ & 1.523 & 2.107 & 1.03 & $-60 . \ldots \ldots$ & 1.540 & 2.087 & .98 \\
\hline$-20 \ldots$ & 1.512 & 2.103 & 1.02 & $-70 . \ldots \ldots$ & 1.526 & 2.091 & .97 \\
\hline
\end{tabular}

$a$ Based on potentiometer readings.

$b$ Interpolated values based on electrometer readings.

The voltage of the cells during test was measured by three different methods, but the open circuit measurements at the lowest 
temperatures could be made only by an electrometer. This instrument was loaned to us by the Department of Terrestrial Magnetism. The open circuit voltages were also measured on a $20000 \mathrm{ohm}$ potentiometer, which afforded a very sensitive method

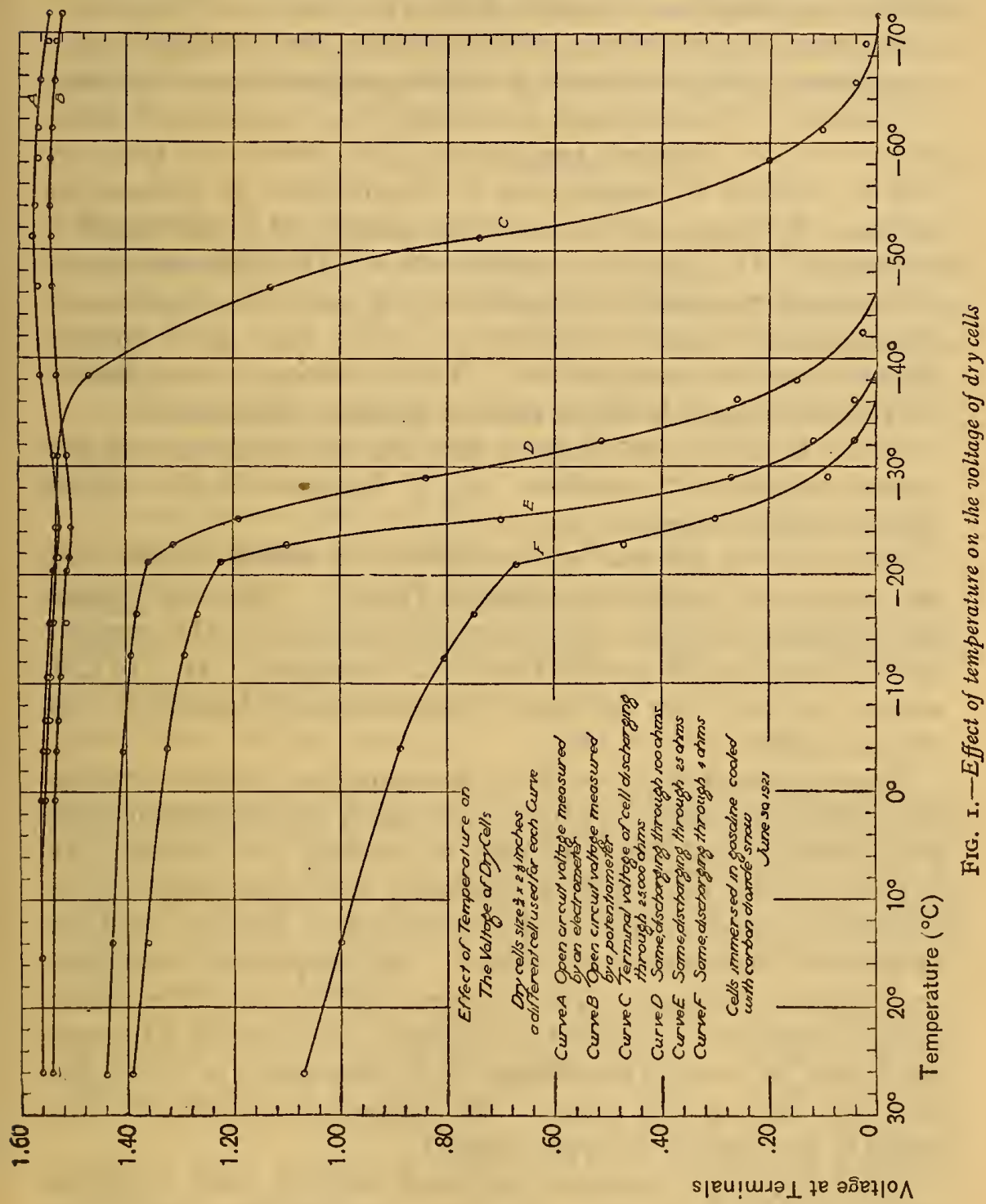

before the cells were frozen, although after this it was nearly useless. A voltmeter having a scale of 2.5 volts and a resistance of 25000 ohms was used for some of the measurements.

The results of experiments with dry cells of the ordinary type are shown in Table I and Fig. I. Curves $A$ and $B$ represent the $88975^{\circ}-22-2$ 
open circuit voltages as measured for two different cells by the electrometer and the potentiometer. Curves $C, D, E$, and $F$ represent the terminal voltage when the cells were discharging through 25000 , roo, 25 , and 4 ohms, respectively. The curves indicate the existence of a critical point at about $-2 \mathrm{I}^{\circ} \mathrm{C}$.

The open circuit voltage curves indicate that changes in the temperature coefficient occur at certain temperatures. Between +26 and $o^{\circ} \mathrm{C}$ the coefficient was found to be constant and somewhat less than a millivolt per degree. The coefficient is positive; that is, increase in temperature is accompanied by increase in voltage. Between o and $-20^{\circ} \mathrm{C}$ the coefficient is still positive but larger. At $-20.4^{\circ} \mathrm{C}$ a break occurs. The temperature coefficient becomes much larger during the next few degrees and then changes to negative at about $-24^{\circ} \mathrm{C}$. At $-54^{\circ} \mathrm{C}$ the coefficient again becomes positive. It is interesting to note that at $-54^{\circ} \mathrm{C}$ the voltage is higher than at ordinary temperatures.

Curves $C, D, E$, and $F$ show that the ordinary dry cell can deliver current down to about $-20^{\circ} \mathrm{C}$, below which the voltage falls off rapidly to zero.

Silver chloride dry cells were measured in a similar manner, and the open circuit voltages are given in Table $\mathrm{r}$. When the voltage was measured by the 25 ooo-ohm voltmeter, however, the terminal voltage began to fall rapidly from $0^{\circ} \mathrm{C}$ downward. At - Io $\mathrm{C}$ it was 0.9 volt, and from this point it decreased nearly linearly to 0.05 volt at $-50^{\circ} \mathrm{C}$.

Experiments were also made to determine the voltage of storage cells within the range +25 to $-72^{\circ} \mathrm{C}$, using the electrometer, the potentioneter, and the voltmeter to measure the voltage. As freezing did not occur within this range, the potentiometer gave the most accurate results, as shown in Table $r$, but the results of all methods were in good agreement. The temperature coefficient was small and constant. This fact permitted an accurate estimate of the temperature coefficient to be made, since the cell had sufficient time for thermal equilibrium to be established at the beginning and end of this range. The temperature coefficient was found to be 0.000398 volts per degree $\mathrm{C}$.

It is interesting to compare this result with the value computed from the available thermochemical data and the Gibbs-Helmholtz equation. This equation is usually written

$$
Q=W-T \frac{d W}{d T}
$$


where $Q$ is the heat of the reaction, $W$ the available work, and $T$ the absolute temperature. This equation is applicable to a reversible cell in which the passage of current does not involve any appreciable change in volume. If $E$ denotes the open circuit voltage of the cell, $W$ equais $96500 E$ volt coulombs ${ }^{1}$ for one equivalent. $Q$ expressed in calories may be converted to volt coulombs by multiplying by 4.183 , and the equation becomes:

$$
\frac{d E}{d T}=\frac{1}{T}(E-0.000021674 Q) .
$$

Both $E$ and $Q$ are dependent on the concentration of the electrolyte, which for this experiment was of $1.28 \mathrm{o} \mathrm{sp}$. gr. The value of $E$ corresponding to the initial value $T$ was observed directly. The value for $Q$ may be calculated from published thermochemical data.

The commonly accepted reaction of the lead accumulator during discharge may be described by the following equation:

$\left.\begin{array}{l}\text { Positive plate, } \mathrm{PbO}_{2}+\mathrm{H}_{2} \mathrm{SO}_{4} \\ \text { Negative plate, } \mathrm{Pb}+\mathrm{H}_{2} \mathrm{SO}_{4}\end{array}\right\}+\mathrm{N} \cdot \mathrm{H}_{2} \mathrm{O} \rightarrow 2 \mathrm{PbSO}_{4}+(\mathrm{N}+2) \mathrm{H}_{2} \mathrm{O}$,

where $N$ is the number of molecules of water to 2 molecules of sulphuric acid in the original solution. The corresponding thermochemical equation is

$$
\mathrm{PbO}_{2}+\mathrm{Pb}+2 \mathrm{H}_{2} \mathrm{SO}_{4}+\mathrm{N} \cdot \mathrm{H}_{2} \mathrm{O}=2 \quad \mathrm{PbSO}_{4}+(\mathrm{N}+2) \mathrm{H}_{2} \mathrm{O}+Q_{\mathrm{N}} \text {, }
$$

where $Q_{N}$, the heat of the reaction, depends on the dilution of the acid, which is fixed by $N$. Since the chemical reaction must take $\mathrm{H}_{2} \mathrm{SO}_{4}$ from the dilute electrolyte, the energy represented by $Q_{\mathrm{N}}$ for other strengths of acid will be less in amount by the quantity of heat evolved by dilution of the acid, or $Q_{\mathrm{N}}$ will be greater if the concentration is greater.

Values for $Q$ have been determined by Streintz ${ }^{2}$ and Tscheltzow ${ }^{3}$ to be 87000 and 88600 calories, respectively. The mean of their determinations is 87800 calories. Dolezalek ${ }^{4}$ states that these values apply to dilute sulphuric acid ( $\mathrm{I} \mathrm{mol} \mathrm{of} \mathrm{H}_{2} \mathrm{SO}_{4}$ to about 400 mols of $\mathrm{H}_{2} \mathrm{O}$ ), and hence a correction for the heat of dilution is necessary. The heat of dilution ${ }^{5}$ of the acid solution from a

\footnotetext{
'The value 96500 coulombs is based on recent determinations with the silver and iodine voltameters by Vinal and Bates at the Bureau of Standards, B. S. Sci. Papers, No. $2 \times 8$.

${ }^{2}$ Wied. Ann., 53, p. 698 ; 1894 .

${ }^{3}$ C. R., 100 , p. $1458 ; x 885$.

Theory of the lead accumulator, p. 29.

'Thomsen's data, Landolt and Bornstein tables, 4 ed., p. $88_{5}$.
} 
specific gravity of 1.280 as used in our experiment to the concentration equivalent to $\mathrm{x} \mathrm{mol}$ of acid to $399 \mathrm{mols}$ of water is $22 \mathrm{Io}$ calories per mol. Two mols are involved, and hence the value for the heat of the reaction for an electrolyte of 1.280 specific gravity is $87800+4420=92220$ calories.

The value for $E$ at $25^{\circ} \mathrm{C}$ and electrolyte of specific gravity I.280 was 2.120 volts. The temperature, $25^{\circ} \mathrm{C}$, corresponds to $298^{\circ}$ absolute. Substituting these values for $T, E$, and $Q$ in equation (2) the value for the temperature coefficient $\frac{d E}{d T}$ is found to be 0.000407 . The results of the experiment showed a decrease in the open circuit voltage of 0.0386 volts when the temperature was decreased $97^{\circ} \mathrm{C}$, from which $\frac{d E}{d T}=0.000398$.

The agreement of this observed value with that calculated from thermochemical data is better than would be expected and gives a striking proof of the validity of the Gibbs-Helmholtz equation over a wide range of temperature.

A second series of measurements extending the temperature range down to $-170^{\circ} \mathrm{C}$ was then made. Only the electrometer readings are of value at this low temperature. The results on a dry cell and a storage cell are shown graphically in Fig. 2. These are the open circuit voltages measured electrostatically. The storage cell showed marked undercooling of the electrolyte before freezing began. The dry cell showed a considerable increase in voltage at $-112^{\circ} \mathrm{C}$ over the normal value. The most remarkable facts are the reversal of voltages and the extraordinarily large values of voltage exhibited by the storage cell, exceeding Io volts at the lowest temperatures. The current was, of course, vanishingly small.

Nernst's equation applied to the storage battery in accordance with Liebenow's theory ${ }^{6}$ is as follows:

$$
E=\frac{R T}{2} \ln \frac{C_{p} C_{n}}{\left[\mathrm{~Pb}^{++}\right]\left[\mathrm{PbO}_{2}^{--}\right]},
$$

where $\mathrm{C}_{p}$ and $\mathrm{C}_{n}$ are the solution tensions of the positive and negative active material and the bracketed values represent the corresponding ionic concentrations. It is evident that a decrease in the ionic concentrations would result in an increase in the value of $E$ if other quantities remained the same.

'Zs. f. Elektrochem., 3, D. 525; 1897. 
No ready explanation of the reversal of voltage is available unless it be assumed that the variation of solution tension of each electrode with temperature is such that curves representing them would intersect at the temperature at which reversal occurs. Pressure may have had something to do with the voltage variations, since the electrometer showed violent fluctuations whenever the frozen electrolyte of the storage cell "ticked." Ice below the freezing temperature sometimes makes a similar ticking sound.

The genuineness of the reversed voltage was shown by the following observations: The dry cell after showing a steady reversed voltage of about I.4 volts was removed from the liquid air, and in the course of a few minutes the reversed voltage decreased steadily, passed through zero, and increased to a normal positive value. Secondly, the potentiometer used for simultaneous measurements with the electrometer on the storage cell retained enough sensibility to show that the potential was reversed at the same time that the electrometer showed a reversed reading.

All of the cells, including the ordinary type of dry cell, the silver chloride cells, and the storage cells, appeared to be entirely normal after being thawed out. The glass test tube containing the storage cell was not broken.

The experiments in the range +25 to $-72^{\circ} \mathrm{C}$ answer completely the practical questions which prompted the investigation. The thermodynamic theory as expressed in the Gibbs-Helmholtz equation is accurately confirmed by the measurements on a storage cell. At temperatures down to $-r 70^{\circ} \mathrm{C}$ points of theoretical interest were found. These suggest that potential differences of normal value at ordinary temperatures may be greatly magnified at extremely low temperatures when the current is vanishingly small. High atmospheric potentials sometimes observed may have some relation to this effect.

We wish to acknowledge the loan of the electrometer by Dr. L. A. Bauer, Director of the Department of Terrestrial Magnetism, and the assistance of Dr. Mauchly in taking some of the observations; also valuable suggestions by Dr. E. Buckingham.

WASHINGTON, January 6, ig22. 